\title{
The finding of diamond squid Thysanoteuthis rhombus in the Gulf of Tehuantepec, Northeastern Tropical Pacific
}

\section{El hallazgo del calamar diamante Thysanoteuthis rhombus en el Golfo de Tehuantepec, Paćfico tropical noreste}

\author{
María del Carmen Alejo-Plata ${ }^{1}$ and Brian Urbano-Alonso²
}

Universidad del Mar, Campus Puerto Ángel. Ciudad Universitaria, Puerto Ángel, Municipio de San Pedro Pochutla, Oaxaca, 70902. México ${ }^{2}$ Facultad de Ciencias, Universidad Nacional Autónoma de México Circuito exterior s/n, Coyoacán, Cd. Universitaria, Ciudad de México, 04510. México e-mail: plata@angel.umar.mx

Recibido: 30 de mayo de 2017.

Aceptado: 22 de diciembre de 2017.

Alejo-Plata M. C. and B. Urbano-Alonso. 2018. The finding of diamond squid Thysanoteuthis rhombus in the Gulf of Tehuantepec, Northeastern Tropical Pacific. Hidrobiológica 28 (1): 147-150. DOl: 10.24275/uam/izt/dcbs/hidro/2018v28n1/Alejo

\section{ABSTRACT}

Background. The presence of Thysanoteuthis rhombus Troschel, 1857 in the eastern Pacific Ocean was estimated based on the geographic range of the species constructed from scattered locations of adults, juveniles, and egg masses. Goals. This note describes morphometric characteristics of the southernmost registry of the diamond squid $T$. rhombus in Mexican waters of the Gulf of Tehuantepec $\left(16^{\circ} \mathrm{N}-95^{\circ} \mathrm{W}\right)$. Methods. In January 2015 we found a stranded adult female weighing a total of $12.5 \mathrm{~kg}$, with a total length of $92 \mathrm{~cm}$, and a mantle length of $45.5 \mathrm{~cm}$. Results. This was a mature female, with oocytes inside the oviducts that averaged $1.2 \mathrm{~mm}$ in diameter, and seven attached spermatophores on the buccal membrane of the female, as evidence of mating. Conclusions. This late registry in the Gulf of Tehuantepec could simply be due to their relative scarcity in the eastern Pacific Ocean.

Keywords: Cephalopoda, Gulf of Tehuantepec, Thysanoteuthis rhombus

\section{RESUMEN}

Antecedentes. La presencia de Thysanoteuthis rhombus Troschel, 1857 en el Océano Pacífico oriental se estimó en función del rango geográfico de las especies, construidas a partir de lugares de dispersión de adultos, juveniles y masas de huevos. Objetivos. La presente nota describe las características morfométricas del registro más sureño del calamar $T$ rhombus en aguas mexicanas (Golfo de Tehuantepec, $16^{\circ} \mathrm{N}$ $95^{\circ} \mathrm{W}$ ). Métodos. En enero de 2015 encontramos una hembra adulta de $12.5 \mathrm{~kg}$ de peso total, $92 \mathrm{~cm}$ de largo total y $45.5 \mathrm{~cm}$ de ancho del manto. Resultados. El espécimen correspondió a una hembra madura, con ovocitos dentro de los oviductos con un promedio de $1.2 \mathrm{~mm}$ de diámetro, además se registró siete espermatóforos adheridos en la membrana bucal de la hembra como evidencia de apareamiento. Conclusiones. Este registro tardío en el Golfo de Tehuantepec podría deberse simplemente a su relativa escasez en el Océano Pacífico oriental.

Palabras clave: Cephalopoda, Golfo de Tehuantepec, Thysanoteuthis rhombus

The diamond squid Thysanoteuthis rhombus Troschel, 1857 is the single species of the family Thysanoteuthidae. It is one of the largest cephalopods, with maximum mantle lengths of both sexes of $100 \mathrm{~cm}$ (possibly to $130 \mathrm{~cm}$ ), and maximum body weight of 24 to $30 \mathrm{~kg}$ (Roper and Jered, 2010). This squid is unique insofar as it is monogamous, living in stable couples throughout most of their life cycle (Nigmatullin et al., 1995).

Thysanoteuthis rhombus is widely distributed in warmer waters (Guerra et al., 2002), although their presence in many tropical and subtropical countries has not been completely confirmed. It is commercially fished in the Sea of Japan but is apparently very scarce in other parts of the world (Miyahara et al., 2008). Findings of adults in other regions occurs when specimens are stranded or caught near the surface, most of whom are probably at the end of their life cycle (Sartor et al., 2008). It is an epi-mesopelagic oceanic squid that rarely approaches the continental shelf zone, but is driven there by warm currents in the peripheral range of the species. Paralarvae and juveniles live in the epipelagic zone, while subadults and adults make daily vertical migrations in the upper 600 to $800 \mathrm{~m}$ depth (Nigmatullin \& Arkhipkin, 1998). They lay characteristic egg masses that float on the surface of the ocean (Guerra et al., 2002)

The presence of $T$. rhombus in the eastern Pacific Ocean was estimated based on the geographic range of the species constructed from scattered locations of adults, juveniles, and egg masses (Nigmatullin et 

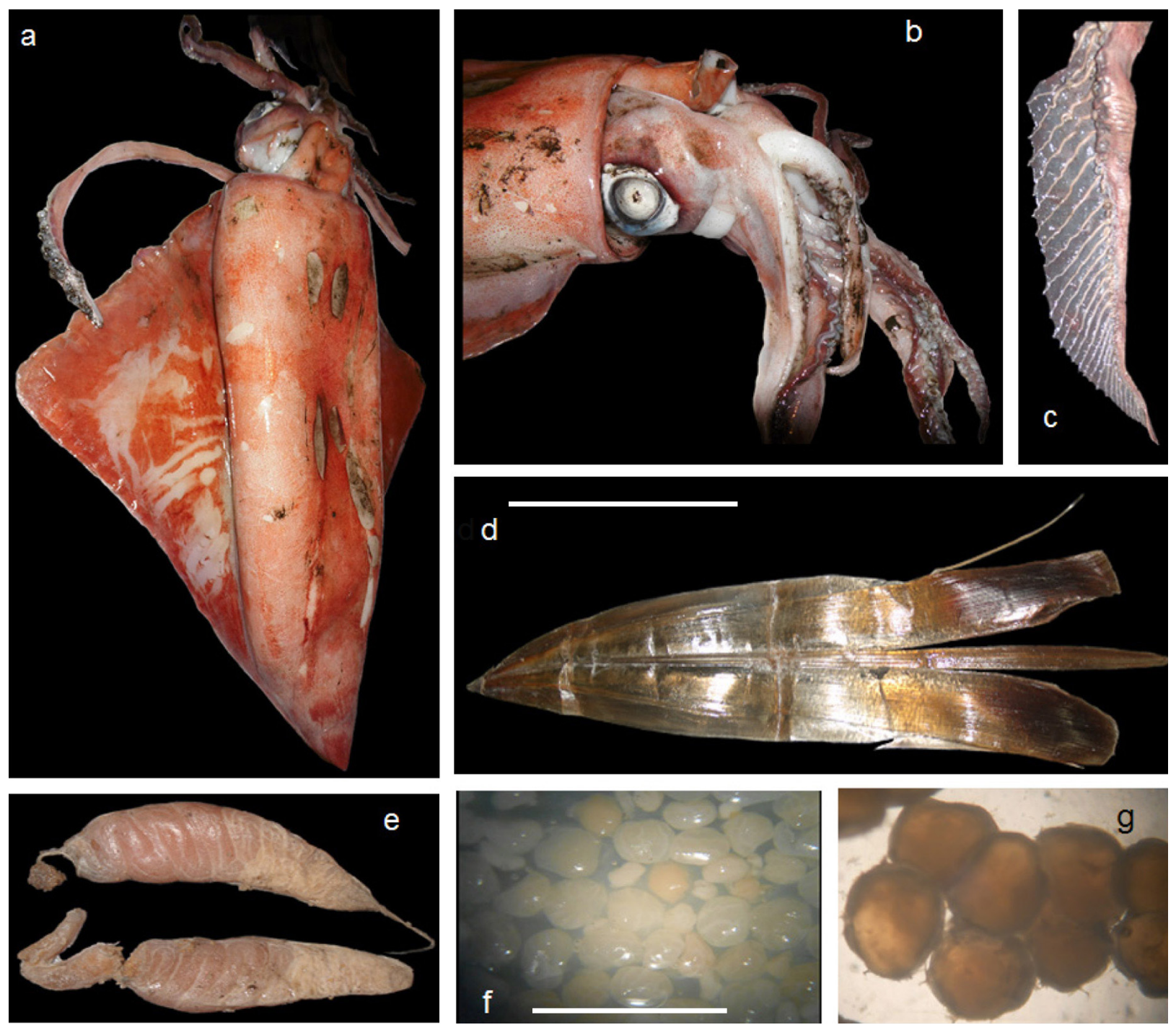

Figures 1a-g. Thysanoteuthis rhombus Troschel, 1857, adult female stranded on 30 January 2015, Salina Cruz, Oaxaca, Mexico. a) Ventral view (ML= 45.5 cm); b) Head; c) Veil arm III; d) Dorsal view of gladius (51 cm); e) Oviducts; f) Oocytes in ovary; g) Oocytes in oviducts. Scale bars: a-d = $20 \mathrm{~mm}$; $\mathrm{e}-\mathrm{g}=1 \mathrm{~mm}$.

al., 1995; Nigmatullin \& Arkhipkin, 1998). It is an elusive species. They never appear in meso-scale detailed studies about squid (GranadosAmores, 2008). Their paralarvae could be collected from the Gulf of Tehuantepec (Alejo-Plata et al., 2013) or the Gulf of California (De Silva et al., 2015). A single registry was reported from the Gulf of California (Hendrickx et al., 2007). In the Baja California Peninsula, T. rhombus has been recorded only from stomach contents of their predators (GalvánMagaña et al., 2013). This species appears to replace large jumbo squid (Dosidicus gigas (d'Orbigny, 1835)) in the swordfish diet when the latter are absent, and few records exist from the California Current (Markaida \& Hochberg, 2005). The aim of this note is to register the southernmost record for T. rhombus in México.

A female (45.5 cm mantle length, $\mathrm{ML}$ ) was found dying and stranded on Punta Chivo, a rocky promontory located about $20 \mathrm{~m}$ away from the coast opposite Bahia Guelaguichi in the Gulf of Tehuantepec $\left(16.103^{\circ} \mathrm{N}, 95.278 \mathrm{~W}\right)$ on 20 January 2015 . The morphological characters fully agreed with the diagnostic features of the species (Roper \& Jereb, 2010). Meristic data, sex, and maturity stage were recorded (Table 1). Because the mantle was damaged, only head, arms, and the gladius were preserved in $70 \%$ ethanol in the cephalopod collection at the Universidad del Mar, Puerto Ángel, Oaxaca, Mexico (reference number MHNUMAR-CEPHA 5101).

We reported a mature female (Table 1), with oocytes inside the oviducts that averaged $1.2 \mathrm{~mm}$ in diameter. We found 7 attached spermatophores on the buccal membrane of the female, as evidence of mating. The complex morpho-ecological adaptations of $T$. rhombus are reflected in the distinctive features of the reproductive system (Nigmatullin et al., 1991). We observed very large oviducal glands, small oviducts in 
Table 1. Morphometric characters of the adult female of Thysanoteuthis rhombus Troschel, 1857, collected in the Gulf of Tehuantepec, Mexico.

\begin{tabular}{|c|c|c|c|c|}
\hline Characters & & & & \\
\hline Mantle length (cm) & 45.5 & & & \\
\hline Total length (cm) & 92 & & & \\
\hline Total weight (kg) & 12.5 & & & \\
\hline Head length (cm) & 9.5 & & & \\
\hline Head width (cm) & 14 & & & \\
\hline Fin length (cm) & 42 & & & \\
\hline Fin width (cm) & 40.5 & & & \\
\hline Eye diameter (cm) & 4.28 & & & \\
\hline Ovary weight (g) & 750 & & & \\
\hline \multicolumn{5}{|l|}{ Nidamental glands } \\
\hline Length (cm) & 22.75 & & & \\
\hline Weight (g) & 625 & & & \\
\hline Arm length $(\mathrm{cm})$ & 1 & $\|$ & III & IV \\
\hline Right (cm) & 16 & 16 & 25 & 15 \\
\hline Left (cm) & 16.4 & 16 & 26 & 15.5 \\
\hline Tentacle (cm) & 33.5 & & & \\
\hline Gladius length & $51 \mathrm{~cm}$ & & & \\
\hline Gladius weight (g) & $10 \mathrm{~g}$ & & & \\
\hline $\mathrm{LRL}(\mathrm{cm})$ & 4.3 & & & \\
\hline
\end{tabular}

$\mathrm{LRL}=$ Rhachis length

comparison with the ovary size, and a straight distal portion (Fig. 1e). Oocytes from the ovary were at various stages of development, thus exhibiting asynchronous development. It was possible to distinguish six size groups of oocytes (0.02 to $1.1 \mathrm{~mm}$ diameter (Figs 1f-g)). This suggests that the squid has multiple spawnings of the pulsate type as mentioned by Nigmatullin et al. (1995). The potential fecundity in both oviducts was 146,000 eggs, which is in the range reported in other studies (Roper \& Jereb, 2010).

This squid has one of fastest growth rates among cephalopods. Life span is about one year, and males and females mature when they are eight months old (Nigmatullin \& Arkhipkin, 1998). Commonly, individuals mature at $85 \mathrm{~cm} \mathrm{ML}$ or more (Nigmatullin et al., 1995). The size of the present specimen $(45.5 \mathrm{~cm} \mathrm{LM})$ is very similar to that of the small mature specimens collected in the equatorial and adjacent waters $(\mathrm{ML}$ $42-50 \mathrm{~cm}$ ) (Nigmatullin et al., 1995), suggesting that there is a smallsized mature group.

The Gulf of Tehuantepec is characterized by its continental shelf, which widens to the east, reaching a maximum width of $106.8 \mathrm{~km}$ at 93-94 $\mathrm{W}$, and stretches to the west, with a minimum amplitude of $\sim 17.8 \mathrm{~km}$ at $95.5^{\circ} \mathrm{W}$. There are two main climatic seasons: one is dry (November to April), and the other is rainy (May to October). High seasonal productivity and low sea-surface water temperature are due to strong vertical mixing and entrainment associated with mountain gap winds (Trasviña \& Barton, 1995), mainly from November to April. The unusual stranding of $T$. rhombus may be related with this upwelling. This squid is an epipelagic to mesopelagic species that inhabits open ocean water, rarely approaching the coast, has a passive migration, and is regulated by oceanographic conditions (Miyahara et al., 2008). This late record in the Gulf of Tehuantepec could simply be due to their relative scarcity in the eastern Pacific Ocean.

\section{ACKNOWLEDGMENTS}

We thank Mr. Francisco Muñoz Cuadras and Omar Valencia for collecting the Thysanoteuthis rhombus specimen. We thank and fully appreciate the critical review of Chingis Nigmatullin and editor, for their helpful comments on the draft manuscript. The manuscript benefited from suggestions and recommendations from anonymous reviewers. This study was supported by the Universidad del Mar Campus Puerto Ángel. BU acknowledges the "Programa de Posgrado en Ciencias Biológicas", UNAM, for financial support during his stay in Mazatlán and CONACYT for a research grant (number 175768).

\section{REFERENCES}

Alejo-Plata, M. C., R. García-Guillén \& J. E. Herrera-Galindo. 2013. Paralarvae and juvenile of cephalopods in the Mexican South Pacific. Hidrobiológica 23 (2): 250-264.

De Silva, D. R., D. E. Godínez, J. Gómez-Gutiérrez \& R. Avendaño-Ibarra. 2015. Cephalopod paralarval assemblages in the Gulf of California of during 2004-2007. Marine Ecology Progress Series 520: 123-141 D0I:10.3354/meps11074.

Galván-Magaña, F., C. Polo-Silva, S. Hernández-Agullar, A. Sandoval-Londoño, M. Ochoa-Diaz, N. Aguilar-Castro \& D. Castañeda-Suárez. 2013. Shark Predation on Cephalopods in the Mexican and Ecuadorian Pacific Ocean. Deep Sea Research Part II: Tropical Studies in Oceanography 95: 52-62. D0l:10.1016/j.dsr2.2013.04.002i

Granados-Amores, J. 2013. Taxonomía de Calamares de la Familia Loliginidae en el Pacífico Mexicano. Tesis de Doctorado (Biología Marina). Centro de Investigaciones Biológicas del Noreste, S.C. La Paz, Baja California Sur, México. 165 p.

Guerra, A., A. F. González, F. J. Rocha, R. Sagarminaga \& A. Cañadas. 2002. Planktonic egg masses of the diamond-shaped squid Thysanoteuthis rhombus in the eastern Atlantic and the Mediterranean Sea. Journal of Plankton Research 24: 333-338. D0I:10.1093/ plankt/24.4.333

Hendrickx, M. E., R. C. Brusca, M. Cordero \& R. G. Ramírez. 2007. Marine and brackish-water molluscan biodiversity in the Gulf of California, Mexico. Scientia Marina, Barcelona (Spain) 71 (4): 637-647.

Markaida, U. \& F. G. Hochberg. 2005. Cephalopods in the diet of swordfish (Xiphias Gladius) caught off the west coast of Baja California, Mexico. Pacific Science 59 (1): 25-41. D0I:10.1353/psc.2005.0011

Miyahara, K., T. Ota, J. Hatayama, Y. Mitsunaga, T. Guto \& G. Onitsuka. 2008. Tagging studies on diamond squid (Thysanoteuthis rhombus) in the western Sea of Japan. Bulletin of the Japanese Society of Fisheries Oceanography 72 (1): 30-39. 
Nigmatuluin, C. M. \& A. I. ARKhipkin. 1998. A review of the biology of the diamondback squid, Thysanoteuthis rhombus (Oegopsida: Thysanoteuthidae). In: Okutani T. (Ed.). International Symposium on Large Pelagic Squids. Japan Marine Fishery Resources Research Center, Tokio, pp. 155-181.

Nigmatuluin, C. M., A. I. Arkhilpkin \& R. M. Sabirov. 1991. Structure of reproductive system of the squid Thysanoteuthis rhombus (Cephalopoda: Oegopsida). Journal of Zoology 224: 271-283. DOl:10.1111/j.1469-7998.1991.tb04804.x

Nigmatuluin, C. M., A. I. ArkHiPkin \& R. M. Sabirov. 1995. Age, growth and reproductive biology of diamond-shaped squid Thysanoteuthis rhombus (0egopsida: Thysanoteuthidae). Marine Ecology Progress Series 124: 73-87. D0I:10.3354/meps124073
Roper, C. F. E. \& P. Jereb. 2010. Cephalopods of the world. An annotated and illustrated catalogue of species known to date. Volume 2. Myopsid and Oegopsid Squids. FA0. Roma, pp. 384-387.

Sartor, P., A. Ligas, M. Sbrana \& P. Belcari. 2008. Notes on large specimen of Thysanoteuthis rhombus (Cephalopoda: Thysanoteuthidae) caught in the northern Tyrrhenian Sea. Biology Marine of Mediterranean 15 (1): 354-355. D0I:10.1017/S1755267208000146

Clarke, M. R. 1996. Cephalopod as Prey. In role of cephalopods in the world's Oceans. Philosofal Transactions: Biological Science 351 (1343): 1067-1081. DOI:10.1098/rstb.1996.0088

Trasuiña, A. \& E. D. Barton. 1997. Los Nortes del Golfo de Tehuantepec: Dinámica del océano costero. In: Lavin, M. F. (Ed.). Contribuciones a la Oceanografía Física en México, Monografía No. 3. Unión Geofísica Mexicana. México, pp. 25-46. 